\title{
Definition as a Means of Semantization in the Dictionaries of Linguistic Terms
}

\section{Assel Meyramovna Akhmetbekova}

\author{
S. Toraighyrov Pavlodar State University
} assel_am@mail.ru

\section{Ariya Khaziyevna Azamatova}

\author{
Al-Farabi Kazakh National University
} ariya_azamatova@mail.ru

\section{Doi:10.5901/mjss.2015.v6n4s2p469}

\begin{abstract}
The article is devoted to the definition as the main means of term semantization and systematization of terminological knowledge in specialized dictionaries. Among all the ways of explanation and fixation of term semantics the definition is more predominant and significant. The aim of this research is a comparative study of the definition as the main means of semantization in dictionaries of linguistic terms in Kazakh, Russian and English. Semantization in scientific and technical lexicography is defined as a semantic, logical-conceptual analysis, which includes all the possible ways of disclosure of the term meaning in a specialized dictionary. In terminology the definition may not exist in isolation. It is considered as a part of the information fixing the term. The main aim of any terminological dictionary is to identify the meaning and fix it in the form of definition. The accurately formulated definition is of great scientific importance. The main task of the definition is not to state or describe, but only to identify and outline the object or subject that will be discussed in the future and will be stated. Such methods as descriptive, typological, definitional and comparative are applied to achieve the main aim of this research. Lexicographic fixation allows the definition with partial features of explanation. Generalization of features of the definition form and content, based on the lexicographic materials, highlights its three types: generic-specific, operational and enumerative. Revealing the most important information in the object, the terminological definition emphasizes it, distinguishes it from other objects and warns against mixing the concepts, confusion in the arguments.
\end{abstract}

Keywords: term, definition, definiendum, definiens, terminological dictionary

\section{Introduction}

The problem of the description of the term meaning is the basic and more effortful in terminological dictionaries of explanatory type. In terminography the semantic level or the zone of description of the term meaning in most cases is central within the study of the dictionary microstructure.

The explanation of the term meaning is based on:

1) a scientific definition - a strict definition formed in accordance with the rules of formal logic;

2) a dictionary explanation, when the dictionary performs a descriptive function and the definition of a term bears the preliminary nature;

3) a referential definition which is given by reference to another definition of the term;

4) an illustrative definition - the illustrative material can act as a graphic presentation, a formula, a diagram, a table, etc .;

5) a contextual definition - an example of the term use in the context where the term meaning is disclosed;

6) an encyclopedic definition where the term meaning is defined with the involvement of a large number of extralinguistic and explanatory material (Grinev, 1993).

It follows that the definition is not the only way to explain the meaning of specialized vocabulary. However, among all the ways of explanation and fixation of the term semantics the definition is the most significant. First, with the help of definition the conceptual side of a sign is identified. Second, the definition is characterized by its conciseness and accuracy. For some researches the presence of the definition is an obligatory and constituent feature of the term. "The study of the conceptual content of the term, fixed by the definition, comes to the fore studying such issues of a terminological theory as the term semantics, the structure of terminological concepts, etc." (Shelov, 2003).

The main aim of the research is a comparative study of the definition as the main means of semantization in 
dictionaries of linguistic terms in Kazakh, Russian and English. Semantization in scientific and technical lexicography is defined as a semantic, logical-conceptual analysis, which includes all the possible ways of disclosure of the term meaning in a specialized dictionary.

Definition is a type of dictionary definition that clarifies the meaning of a term by listing its essential features and presents the equivalence relation, consisting of a concept to be defined (definiendum - Dfd) and a concept that is used to define (definiens - Dfn). According to the rules of formal logic the definition should be objective, concise, accurate, equal to the volume of definiendum and not contain a logical circle.

Terminological definitions - as a special genre - promote structuring of scientific knowledge, combining with each other on the basis of different connections and relationships. The scientific concept has different forms of expression and semantic representation corresponding to different levels, stages of development of science and scientific abstraction. Therefore, in the content of concept its basic and most significant features are reflected. Different types of definitions reflect a higher level of scientific abstraction (Gerd, 2005).

\section{Methods}

The problems, related to the definition in dictionaries of linguistic terms in the Kazakh, Russian and English languages, required the use of a descriptive method on the basis of which the synchronic analysis of the definition as a means of term semantization is carried out; typological and definitional methods - to define the main types of terminological definition and a comparative method - to identify the common and special in the content of terminological definitions. The descriptive method is applied to describe the content of the definition in dictionaries of linguistic terms at the present point in time. Typological and definitional methods allow distinguishing three main types of definitions: generic-specific, enumerative and operational. The comparative analysis of definitions in dictionaries of linguistic terms confirms that the ways of organization of definitions depend not only on the differential structure of knowledge about the nature of definiendum in different languages but also on the authors of dictionaries.

\section{Main Body}

The term arises as a result of interaction between cognition and communication in the professional sphere. The presence of the definition is an important factor to recognize a lexical unit of the language for specific purposes as a term. In terminology the definition may not exist in isolation. First of all it is considered as a part of the information fixing the term. Consequently, the definition is only a part of the semantic specification including morphological, syntactic and sometimes pragmatic features. The definition with the necessary degree of accuracy can reflect the main characteristics of the object, i.e. clearly point to it, identify it among the other objects and single out its systemic features. The definition is used to define the nature of the term for its use in a particular field of activity. The linguistic description of the term meaning is quite sufficient for the definition. It follows that the main aim of any terminological dictionary is to identify the term meaning and fix it in the form definition. The accurately formulated definition is of great scientific importance. In the process of fixing the term a set of features of the object is reflected for singling it out from the other objects (terms).

In terminology the definition is necessary for:

1) initial fixation of the term - the equality of concepts;

2) identification of the term by the definition;

3) explanation of the concept meaning for specialists (Sager, 1990).

The main function of the definition is to determine the position of the term in a certain structure of knowledge. The definition is applied to those terms that are still not clearly defined and require further specification. Also, many of the terms require the definition for a more complete analysis to establish their relationship with other terms in a particular structure of knowledge.

The main task of the definition is not to state or describe, but only to identify and outline the object or subject that will be discussed in the future and will be stated (Shelov, 2003). Therefore, the definition pretends to the exhaustive nature of verbal identification of definiendum. According to the given quality the definition is of paramount importance in the knowledge structure.

Special knowledge is built through the successful definition and substitution of elements of the common language with special elements to the limit, appropriate to each level of education established by the society which then becomes the primary level for certain types of messages. This process is repeated every time, expanding a particular field and developing new concepts (Sager et al, 1980).

A.S. Gerd notes that "terminological dictionaries of explanatory type give the exact logical definition of a scientific 
concept without conveying its whole content. Common explanatory dictionaries often reflect the everyday concepts ..." (Gerd, 2005). It should be observed that the object of study and ways of its disclosure in terminological dictionaries and general explanatory dictionaries are different, but the function of both types of dictionaries is the same: to clarify the meaning of definiendum.

It follows that the analyzed dictionaries of linguistic terms in Kazakh, Russian and English can be called as terminological dictionaries of explanatory type. First, they are monolingual and aimed at disclosing the meaning of definiendum. Second, definitions with the "soft" conceptual system which have partially features of interpretation are typical for these ones. Dictionaries of linguistic terms are more acceptable for the lexicographic fixation of terminology in humanities where both the accuracy and clarity of understanding is important.

Taking into account the variety of lexicographic definitions, the analysis of dictionaries of linguistic terms in Kazakh, Russian and English reveals that all the definitions are explicit and divided into the following types:

1. Generic-specific definitions define an object or a concrete concept by indicating the genus (genus proximum) and the specifying type trait (differentia specifica). Creating definitions of this type it is necessary to identify the genus and specifying type traits (one or more), which should be the basis of classification of the generic concept and from which the specific features, reflected in definitions of specific concepts, depend on (Volkova, 1986; Shelov, 2003; Bussmann, 2006).

S.D. Shelov offers a method of definitional analysis of generic-specific definitions based on the following rule: "a fragment of definiens naming the genus is a minimal, semantically complete and semantically main independent part of the definiens which includes a maximum (according to lexical and syntactic structure) previously defined term (or a free combination of previously defined terms); the remainder of the definiens represents a formulation of a specifying type trait of the genus (if this part belongs syntactically to one word) or a combination of specifying type traits (if this part belongs syntactically to different words)" (Shelov, 2000).

This method allows defining the generic-specific type of terminological definition more accurately. For example:

S`intaksis - söylemdegi sözderdiň, söz tirkesteriniň baylanysyn, zaňdylyqtaryn, söylem qúraudyň amal-täsilderin zertteytin grammatikanyň bir salasy (Qaliyev, 2005);

SINTAKSIS - chast grammatiki, izuchayushchaya sochetaniya slov v predlozhenii (Zherebilo, 2005);

syntax - the branch of grammar dealing with the organization of words into larger structures, particularly into sentences; ... (Trask, 1993).

In dictionary of linguistic terms in Kazakh the genus proximum of a term is grammatikanyn̆ bir salasy, in dictionary in Russian - chast grammatiki; and in dictionary in English - the branch of grammar. These generic concepts represent a minimal semantically complete part of definiens. The remainders, notably söylemdegi sözderdiň, söz tirkesteriniň baylanysyn, zaňdylyqtaryn, söylem qúraudyn̆ amal-täsilderin zertteytin; izuchayushchaya sochetaniya slov v predlozhenii; dealing with the organization of words into larger structures, particularly into sentences are specifying type traits. Or, for example:

AGGLYuTIN`ATsIYa - tübir sözge, köbine, soňynan jalğanatyn qosymšalar arqyly payda bolatyn tildik qúrylys (negizinde jalağamaly tilge tän erekšilik) (Kenesbayev et al, 1966);

AGGLYuTIN`AtsIYa - mekhanicheskoye prisoyedineniye odnoznachnykh standartnykh affiksov $k$ neizmenyaemym osnovam ili kornyam (Akhmanova, 2004);

agglutination - a type of morphological structure, in which words can be readily divided into a linear sequence of distinct morphemes, each of which has typically a fairly consistent shape and a single consistent meaning or function (Trask, 1993).

In the given generic-specific definitions the generic concepts are: tildik qúrylys, mekhanicheskoye prisoyedineniye affiksov, a type of morphological structure. The remainders of definientia are the specifying type traits. It should be noted that the specifying type traits in definiens of the term are odnoznachnykh standartnykh and k neizmenyaemym osnovam ili kornyam and according to the above-stated method belong syntactically to different words.

2. Enumerative definitions do not possess a generic-specific structure. The conceptual content of definiendum is fixed by listing the elements which enter it as its specific representatives. Impossibility of coincidence of any of the objects mentioned in the list is one of the important characteristics of enumerative definitions. It should be considered that enumerative components are in the structure of formulation of the genus proximum but not differentia specifica (Shelov, 2003).

In the context of enumerative definitions the semantic neutralization of conjunctions is possible. They are jäne, nemese, sonymen qatar in dictionaries in the Kazakh language; $i$, ili, a takzhe in dictionaries in Russian; and, or, as well as in dictionaries in English. However, regardless of the applied conjunction, the definiens of enumerative definitions has one semantic character - a conjunctive connection of components. It follows that if in the generic-specific definition the 
basic structural elements are the genus proximum and the differentia specifica, in the enumerative definition the basic structural elements are its conjunctive components.

For example, in the dictionary of linguistic terms in English the following enumerative definitions can be met:

abstract noun - a noun whose meaning is an abstract concept (truth, beauty, magnitude, consequence) or a noun denoting an event (arrival, explosion) (Trask, 1993);

body language - designation for instinctive, conscious and/or conventional expressive movements of the body (Bussmann, 2006); 1993).

complement clause - a finite or non-finite clause which serves as a complement to some lexical items (Trask,

The conceptual meaning of terms is identified by listing the elements that enter it as its specific representatives. So, a noun whose meaning is an abstract concept and a noun denoting an event are specific representatives of definiendum abstract noun; designation for instinctive movements of the body, designation for conscious movements of the body and designation for conventional expressive movements of the body - specific representatives of body language; a finite clause which serves as a complement to some lexical items and non-finite clause which serves as a complement to some lexical items - specific representatives of definiendum complement clause. It should be noted that in the enumerative definitions the whole syntactic structure is a specific representative of the definiendum.

In dictionaries of linguistic terms in Russian and Kazakh the enumerative definitions can be also observed:

DVOYN'YE F'ORMY - variantnye orfoepicheskiye, orfograficheskiye, morfologicheskiye i drugie formy (Akhmanova, 2004);

KONVERGENTsIYa - skhozhdeniye, vzaimoupotrebleniye elementov yazyka (Zherebilo, 2005);

NEOLOGIZM - novoye slovo ili novoye znacheniye i forma uzhe sushchestvuyushchego slova. ... (Zherebilo, 2005).

In the dictionary in Russian these enumerative definitions point out that variantnye orfoepicheskiye, orfograficheskiye, morfologicheskiye and drugie formy - specific representatives of term dvoynye formy; skhozhdeniye elementov yazyka and vzaimoupotrebleniye elementov yazyka - specific representatives of definiendum konvergentsiya; novoye slovo, novoye znacheniye and novaya forma sushchestvuyushchego slova - specific representatives of definiendum neologism.

ALTAY TILDERI - türki, moňğol, túňğys-manchjúr jəne basqa tilderdiň jiyntyq attary (Kenesbayev, 1966); 2005);

Grafema - tildiň jazu jüyesindegi negizgi birligi, dybystyň jazudağy taňbasy, jazu jüyesiniň eň kiši belgisi (Qaliyev,

SONANTTAR - tonnyň daňğyrdan, šudan basym boluynan jasalatyn buyn qúraušy element, ündi dauyssyz nemese jartylay dauystylar (Suleymenova et al, 1998).

Enumerative definitions in the dictionary in Kazakh, as well as in English and Russian, name objects which enter the structure of definiendum. From the cited examples, türki, moňğol, tún̆ğys-manchjúr jəne basqa tilderdiň jiyntyq attary enter the structure of definiendum altay tilderi; tildiň jazu jüyesindegi negizgi birligi, dybystyn̆ jazudağy taňbasy, jazu jüyesiniň eň kiši belgisi are the specific representatives of definiendum grafema; tonnyn̆ daňğyrdan, šudan basym boluynan jasalatyn buyn qúraušy element, ündi dauyssyz and jartylay dauystylar - specific representatives of definiendum sonanttar.

3. An operational definition is a genetic definition, where the genus is not included. In the operational definition the description of the procedure of the object construction points to the way of its occurrence - the description intended for some cognitive activity of the subject, perceiving the text of definition. It should be observed that this type of definition is most applied in defining the concepts of technical and natural sciences (Shelov, 2003).

In turn, $\mathrm{H}$. Bussmann indicates that an operational (genetic) definition is a special type of real definition. In linguistics the operational definition refers to the origin and method of defining the concept to be defined. Deletion, replacing, adding or reordering are the main means of transformation in this type of definition. For example: phonemes minimal sound elements whose 'exchange' results in a difference in meaning. It should be noted that operational definitions are typical for concepts of structural linguistics and generative (transformational) grammar. The aim of operational definition is to identify and describe language regularities, as well as to establish and assess the linguistic hypotheses and theories (Bussmann, 2006).

Comparing the definitions, introduced by S.D. Shelov and H. Bussmann, the question arises about the content of the operational definition. Studying the theory of definitions, D.P. Gorsky also noted that the problem about the specification of objects to be defined by means of their formation, origin and construction is resolved by genetic definitions. This type of definition is established through the genus proximum and the differentia specifica (Gorsky, 1974).

The study of typology of definitions of linguistic terms allows coming to the conclusion that in the definiens of 
generic-specific definition (real) the genus proximum and the differentia specifica are assigned. The genus proximum is generic with respect to the definiendum and the differentia specifica differentiates the definiendum from the other concepts in a certain field of knowledge. With regard to the operational definition, this definition is a subtype of the real definition, the content of which also consists of the genus proximum and differentia specifica. The difference lies in the fact that the differentia specifica of operational definition does not point to the essential properties of the term, but by transforming the linguistic elements defines its specific features.

The assertion about the lack of genus proximum in operational definitions is relative. In this respect the views of scholars differ. In practice researchers often face the problems of this nature. In this case the field of knowledge should be taken into account where the typology of definitions is considered. Perhaps, in the description of operations of mathematical, physical and chemical concepts the genus proximum is not required, but it is inadmissible for operational definitions in the field of linguistics. For example:

Tektes morfemalar - mağynasy men qyzmeti jağynan úqsas, birin-biri ayyrbastay alatyn qosymša morfemalar (Qaliyev, 2005);

Diakritikalyq belgi - belgili bir dybystyň qosymša artikulyatsiyalyq mağynasyn bildiru üšin äripke qosylatyn šartty kömekši belgi (Qaliyev, 2005);

JALĞAU - söz ben sözdi, söylem men söylemdi jalğastyryp, söz tudyryp, söz özgeretip (türlendirip) túratyn qosymša (Kenesbayev, 1966);

ALTERN'ANT - variant kak chereduyushchysya s drugimi variantami toy zhe empiricheskoy edinitsy, kak svyazanny s drugimi variantami otnosheniyem cheredovaniya (Akhmanova, 2004);

DISFEM'IZM - trop, sostoyashchy $v$ zamene estestvennogo $v$ dannom kontekste oboznacheniya kakogo-I. predmeta boleye vulgarnym, familyarnym ili grubym (Akhmanova, 2004);

Morf ema derivatsi onnaya - affiksalnaya morfema, vidoizmenyayushchaya leksicheskoye znacheniye kornya i obrazuyushchaya novoye slovo (Akhmanova, 2004);

adjunct - a category which is a modifier of a lexical head withiout being subcategorized for by that lexical head and which could in principle removed without affecting well-formedness; e.g., in the sentence I saw Lisa in the park yesterday, the phrases in the park and yesterday are adjuncts of the verb (Trask, 1993);

constituent - any part of a sentence which is regarded as forming a distinct syntactic unit within the overall structure of the sentence, on the ground that it behaves as a unit with respect to certain criteria, such as displacement, coordination, ellipsis and the possibility of its serving as antecedent to a pro-form (Trask, 1993);

infix - an affix which occupies a position in which it interrupts another single morpheme (Trask, 1993).

These examples of definitions in dictionaries of linguistic terms in Kazakh, Russian and English indicate that definiendum of operational definitions contain such generic concepts as qosymša morfemalar; šartty kömekši belgi; qosymša; variant; trop; affiksalnaya morfema; a modifier; any part of a sentence; an affix. Specific features point out the way of transformation of definiendum. So, in definitions in Kazakh tektes morfemalar replace each other; diakritikalyq belgi is added to the letter for its correct articulation; jalğau changes the meaning of words by addition. In definitions in Russian alternant alternates with other variants; disfemizm replaces the natural designation of any object by more vulgar; morfema derivatsionnaya changes the meaning of the root by addition and forms a new word. In definitions in English adjunct can remove in the sentence; constituent removes or is omitted in the sentence; infix interrupts another morpheme, i.e. is put into the stem.

\section{Results}

Thus, it is schematically singled out the main types of definitions in dictionaries of linguistic terms, where $a$ - genus proximum; $b$ - differentia specifica, which differentiates describing the essential features of Dfd; $b$ ' - differentia specifica, which defines the specific features Dfd by transforming the linguistic elements and $c, c^{\prime}, c^{\prime \prime}-$ specific representatives of Dfd:

1) generic-specific definition: Dfd = Dfn: $a+b$;

2) operational definition: Dfd = Dfn: $a+b$ '

3) enumerative definition: $D f d=D f n: c+c^{\prime}+c^{\prime \prime}$.

The definitions of given types in dictionaries of linguistic terms show that, despite the differences in the content of Dfn when defining Dfd, according to the rules of formal logic both concepts are proportional in relation to each other.

Having considered above-stated types of definitions, it should be noted that the definition of concepts plays an important role in the theoretical and practical activities. Expressing knowledge about the object in a concise style, it is a significant moment in the knowledge of reality. 
The semantic level of description of the entry words in dictionaries of linguistic terms indicates that the content of definitions is not of the same type, as their interpretation varies from definition to definition. In the compared dictionaries of linguistic terms such basic types of terminological definitions are observed as generic-specific, operational and enumerative, which are the most basic and commonly used ways of organizing dictionary definitions.

The scientific definition establishes a system of human knowledge about the world at one stage of its development. The study of types of definitions and their differential features is inseparably linked with the study of terms and terminology systems. The comparative analysis of dictionaries of linguistic terms in Kazakh, Russian and English indicates that the verbal expression and functioning of languages, the differential structure of knowledge about the nature of the object (term) in the field of linguistics, its semantic content and special genre affect a variety of types of definitions in dictionaries of linguistic terms.

\section{Conclusion}

Analyzing definitions in dictionaries of linguistic terms, types of definitions as the main means of term semantization go through the qualitative analysis. Despite the different types of definitions in disclosing the term meaning, the volume of definiendum and definiens coincide. In terminological dictionaries of explanatory type the definition can be represented in the form of interpretation, but not every interpretation of the word in common explanatory dictionaries is a definition as the object of the definition is a scientific concept.

In the analyzed dictionaries of linguistic terms the lexicographic fixation allows the presence of the definition with partial features of interpretation. Despite the admissible "softness" of the conceptual system, the definiens of the definition is a substantional lexicographic component supplemented by the illustrative material to identify the term and its adequate performance.

In terminological dictionaries of explanatory type the structure and the method for constructing a definition are based on well-defined logic and linguistic requirements, the observance of which leads to the term fixation. In general, the definition is necessary to preserve the unity of science, integrity and continuity of its basic conceptual apparatus.

For the purpose of inventory and streamlining the corpus of terminological definitions in the compared dictionaries in the scientific article it is made an attempt to systematize and develop their typology on the basis of differentiating features. In the dictionaries of linguistic terms the basic types of terminological definitions are generic-specific, operational and enumerative. The variety of definitions in dictionaries of linguistic terms is explained by the differential structure of knowledge about the nature of the object in the field of linguistics. Disclosing the most important facts in the object, the terminological definition allows to emphasize it, distinguish it from the other objects, warns against mixing the concepts, confusion in the arguments.

The analysis of dictionaries of linguistic terms in Kazakh, Russian and English determines that the ways of definition structure as the main means of term semantization depend on subjective factors of the dictionary occurrence, first of all, the decisions of its writers.

\section{References}

Akhmanova, O. S. (2004). Dictionary of Linguistic Terms. (2nd ed.). Moscow: Editorial URSS.

Bussmann, H. (2006). Dictionary of Language and Linguistics. London and New York: Routledge.

Gerd, A. S. (2005). Applied Linguistics. St. Petersburg: Publishing house of St. Petersburg University.

Gorsky, D. P. (1974). Definition. Moscow: Mysl.

Grinev, S. V. (1993). Introduction to Science of Terminology. Moscow: Moskovsky litsey.

Kenesbayev, S. \& Zhanuzakov T. (1966). Russian-Kazakh Dictionary of Linguistic Terms. (2nd ed.). Almaty: Ğylym.

Qaliyev, Ğ. (2005). Explanatory Dictionary of Linguistic Terms. Almaty: Sözdik-Slovar.

Sager, J. C. (1990). A practical course in terminology processing: with a bibliography by Blaise Nkwenti-Azeh. Amsterdam and Philadelphia: Benjamins Publishing Company, John.

Sager, J. C., Dungworth, D. \& McDonald, P. F. (1980). English special languages: principles and practice in science and terminology. Wiesbaden: Brandstetter.

Shelov, S. D. (2003). Term. Terminologicality. Terminological Definitions. St. Petersburg: Philological Faculty St.PSU.

Shelov, S. D. (2000). To Linguistic Typology of Terminological Definitions. Scientific and Technical Infirmation. Series 2. Informational Processes and Systems: Monthly Scientific and Technical Collected Articles. № 2, 1-9.

Suleymenova, E., Madiyeva, G., Shaimerdenova N., Avakova, R. et al. (1998). Dictionary in Linguistics. Almaty: Ğylym.

Trask, R. L. (1993). A Dictionary of Grammatical Terms in Linguistics. New York: Routledge.

Volkova, I. N. (1986). Modeling Definitions in Terminological Standards. Modern Problems of Russian Terminology, Moskow: Nauka, $140-161$.

Zherebilo, T. V. (2005). Dictionary of Linguistic Terms. (4th ed.). Nazran: 000 "Pilgrim". 